\title{
Influence of unstable weather conditions on the passage time of phenological phases of black currant in the Middle Urals
}

\author{
E. M. Chebotok ${ }^{1 凶}$ \\ ${ }^{1}$ Ural Federal Agrarian Research Center of the Ural Branch of the Russian Academy of Sciences, Ekaterinburg, \\ Russia \\ 区E-mail:sadovodnauka@mail.ru
}

\begin{abstract}
Purpose. The research is aimed at studying the influence of weather conditions on the timing of the phenological phases of black currant in the Middle Urals. Methods. The study is based on methods of phenological observations in accordance with generally accepted methods. Results and practical significance. It was found that black currant adapts well to unstable weather conditions in recent years in the Middle Urals, during the research period, budding was observed in the period from April 12 to May 4; the dates of the beginning of flowering were marked from May 10 to May 28; maturation dates are marked from July 16 to August 10 . The shift in the dates of onset of the main phases of vegetation from the average longterm can reach 14 days. Industrial plantings should consist of varieties of different flowering and maturation periods, to avoid the spring frosts of the main part of the plantation, as well as to form a conveyor for the arrival of fresh berries. The experiment identified five early-flowering cultivars in the Middle Urals: Zabava, Fortuna, 1-3-010-13, 3-2-010-13, 6-44-00-03; four late-flowering: Gerkules, Slavyanka, 5-1-010-13, 8-2-010-13; the remaining 28 cultivars are of the average flowering period. Five varieties of early maturation are identified: Zabava, 2-1-010-13, 2-4-010-13, 3-1-010-13, 5-1-010-15; four late maturation: Zaglyaden'e, Kipiana, Chudnoe mgnovenie, Slavyanka; the remaining 28 varieties are of average maturation. Not all earlyflowering cultivars are early-maturing, and not all late-flowering cultivars are late-maturing. The scientific novelty consists in the study of phenological rhythms of black currant varieties of various genetic origin in unstable weather conditions of recent years in the Middle Urals.
\end{abstract}

Keywords: black currant, introduced varieties, local varieties, phenology, Middle Urals, unstable weather conditions, adaptation.

For citation: Chebotok E. M. Influence of unstable weather conditions on the passage time of phenological phases of black currant in the Middle Urals // Agrarian Bulletin of the Urals. 2020. No. 07 (198). Pp. 23-28. DOI: ... (In Russian.)

Paper submitted: 08.05.2020.

\section{Introduction}

Black currant is one of the leading small-fruit crops grown in the Middle Urals [1, p. 166]. The timing of the onset of the main phenological phases in black currant, as well as in other crops, is genetically determined and is directly dependent on the sum of effective and active temperatures $[2$, p. 147], [3, p. 29], [4, p. 14], [5, p. 35], [6, p. 96], [7, p. 55], [8, p. 234]. In the conditions of the Middle Urals, for the beginning of the growing season (vegetation), the sum of effective temperatures of $41.0-115.0^{\circ} \mathrm{C}$ is required, for flowering $207.0-368.5{ }^{\circ} \mathrm{C}$, for ripening - the sum of active temperatures is $1246.0-1539.0^{\circ} \mathrm{C}$, the end of the growing season 1993.5-2363.0 ${ }^{\circ} \mathrm{C}$. The growing season is $153-195$ days [9, p. 53]. In the initial growing season of black currant, weather conditions in the Middle Urals are unstable, accompanied by sharp fluctuations in temperature. The flowering phase of black currant often coincides with the period of return frosts. The growing seasons of the last three years sharply differed among themselves in temperature indicators and the amount of precipitation, which affected the timing of the onset of the phenological phases of black currant over the years. The cultivars included in the study were introduced from other natural and climatic zones or were selected in the conditions of the Middle Urals and have different genetic origins [10]. Phenological observations have both scientific and practical value, highly adaptive varieties are able to most fully reveal their potential and ensure high productivity [11, p. 233], [12, p. 225], [13, p. 228], [14, p. 66], [15, p. 178], [16, p. 31], [17, p. 117], [18, p. 2]. In connection with the above, a study was carried out of the passage of phenological phases of vegetation by black currant varieties during 2017-2019. at the Sverdlovsk gardening selection station.

The aim of the research is to study the influence of weather conditions on the timing of the phenological phases of black currant in the conditions of the Middle Urals.

\section{Research methods}

Place of work - Sverdlovsk selection station of gardening - a structural subdivision of the Federal State Budgetary Scientific Institution "Ural Federal Agrarian Research Center of the Ural Branch of the Russian Academy of Sciences" on a unique scientific installation of the collection of living plants in open ground "Gene pool of fruit, berry and ornamental crops in the Middle Urals" (Ekaterinburg). 
Observations of varieties and selected forms in phenology were carried out according to the generally accepted methods of variety study of fruit, berry and nut crops [19, p. 351], [20, p. 158]. When carrying out phenological observations, the timing of the onset of phenophases was determined visually in general by replicates. Accounting for the beginning of budding and the timing of flowering was carried out every other day, the timing of ripening - in two days.

The beginning of the growing season (vegetation). Weather conditions in the second - third decade of April have a great influence on the beginning of the growing season, when the average daily temperature in our zone goes over $+5^{\circ} \mathrm{C}$ and, as a rule, buds begin to bloom. Over the years of observation, bud opening was noted in mid-April - early May.

Flowering. On average it started 3-4 weeks after the beginning of the budding phase. Over the years of research, flowering was observed in the second - third decade of May.

Maturation. The ripening of berries in the studied varieties was noted in mid-July - early August, depending on the weather conditions prevailing during the years of observation.

Weather conditions for the period of research are shown in Fig. 1 and 2.

Introduced varieties were used as objects of research: selections of FGBNU VNIISPK (Orel) - Zaglyadienie, Kipiana, Wonderful moment; selection of FGBNU FANTSA (Barnaul) - Hercules, Zabava; varieties and selected seedlings of the selection of the Sverdlovsk selection station of horticulture (32 varieties) of various origins (table 1).

\section{Results}

During the study period, bud breaking was observed in the period from April 12 to May 4; blooming dates are marked from May 10 to 28; ripening period - from July 16 to August 10. The results of phenological observations in this experiment are presented in table 2 .

In 2017, the passage of all phenological phases took place in the usual terms according to long-term average data. Dissolution of buds was observed from 17 to 20 April. Flowering dates are marked May 12-17. Ripening dates are marked from 24 to 29 July.
In 2018, all phenological phases took place at a later date according to long-term average data (shift by 10 days) due to the late melting of the snow cover (April 22) and cold May. In 2018, budding was noted in the period from 1 to 4 May. The beginning of flowering was observed from 23 to 28 May. Ripening was noted from 2 to 10 August. In 2019, budding was observed between April 12 and 17. At this time, there was a sharp cooling down to $-11^{\circ} \mathrm{C}$ with precipitation in the form of snow (on April 16-17, there was noted temporary snow cover) after warm weather (the air temperature during the day rose to $+18.5^{\circ} \mathrm{C}$ ). The dates of the beginning of flowering are marked from May 10 to 14; the flowering period was very tight due to the fact that at this time there was hot weather, the air temperature during the day rose to $+28^{\circ} \mathrm{C}$. The frost was recorded during the formation of the ovary on May 24-26 to $-1.7^{\circ} \mathrm{C}$. Ripening dates are marked from July 16 to 25 (which is 14 days earlier than in 2018 and 7 days earlier than in 2017).

When growing black currants in the Middle Urals in industrial plantations, in order to select a varietal composition, it is especially necessary to take into account the timing of the flowering and ripening phases. The plantings should consist of varieties of different flowering and ripening periods, to avoid spring frosts in the main part of the plantation, as well as to form a conveyor for the supply of fresh berries. In the experiment were identified stable early flowering varieties in the conditions of the Middle Urals: Zabava, Fortuna, 1-3-01013, 3-2-010-13, 6-44-00-03; stably late flowering: Hercules, Slavyanka, 5-1-010-13, 8-2-010-13; the rest of the varieties the average flowering period. Varieties of stably early ripening: Zabava, 2-1-010-13, 2-4-010-13, 3-1-010-13, 5-1-010-15; consistently late ripening: Zaglyadenie, Kipiana, Chudnoe mgnovenie, Slavyanka; the rest of the varieties - the average ripening period.

Not all early flowering cultivars proved to be early maturing, not all late flowering varieties were late maturing. So, only the variety Zabava is early both in terms of flowering and ripening of berries; only the Slavyanka variety is late both in flowering and ripening. Variety 5-1-010-15 late flowering but early ripening.

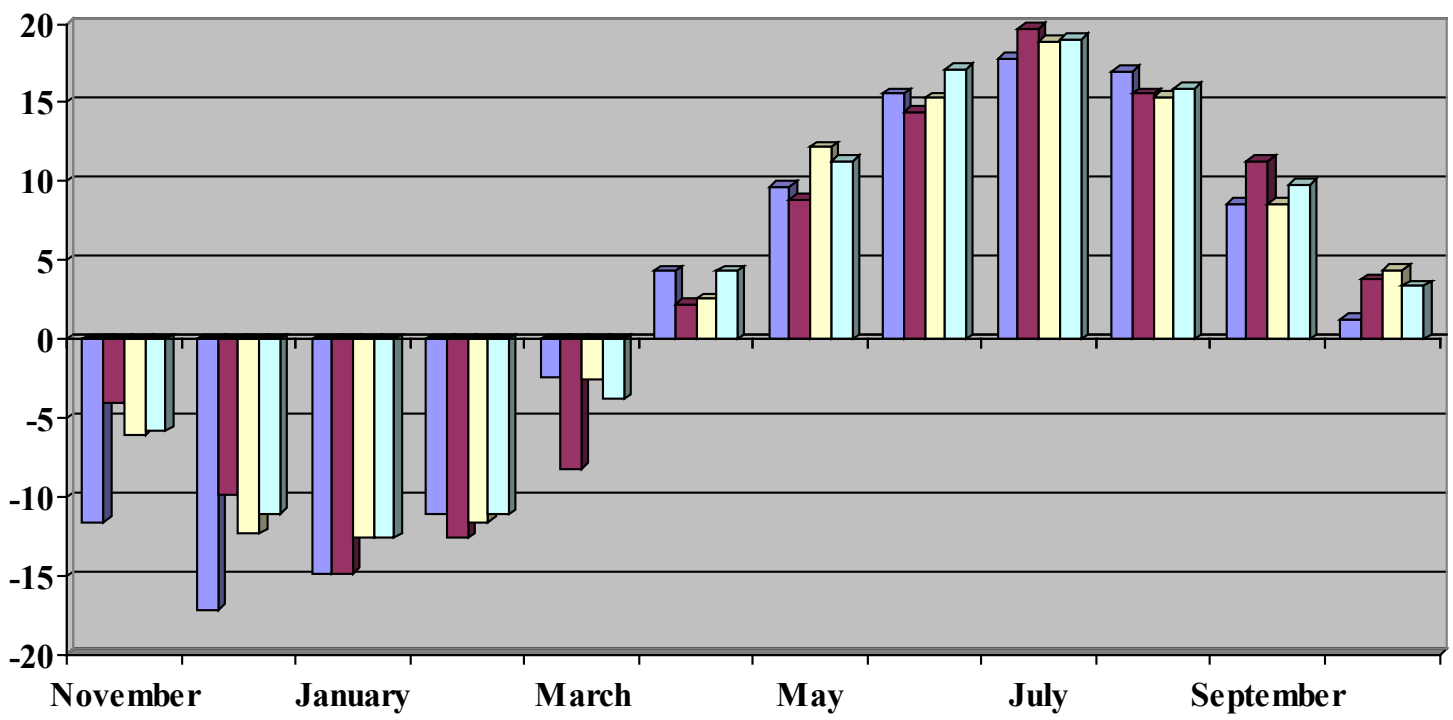

$\square$ 2016-2017

2017-2018 $\square$ 2018-2019 $\square$ Average

Fig. 1. Temperature regime of overwintering and vegetation period of plants in comparison with the average long-term data 


\section{Agrarian Bulletin of the Urals No. 07 (198), 2020}

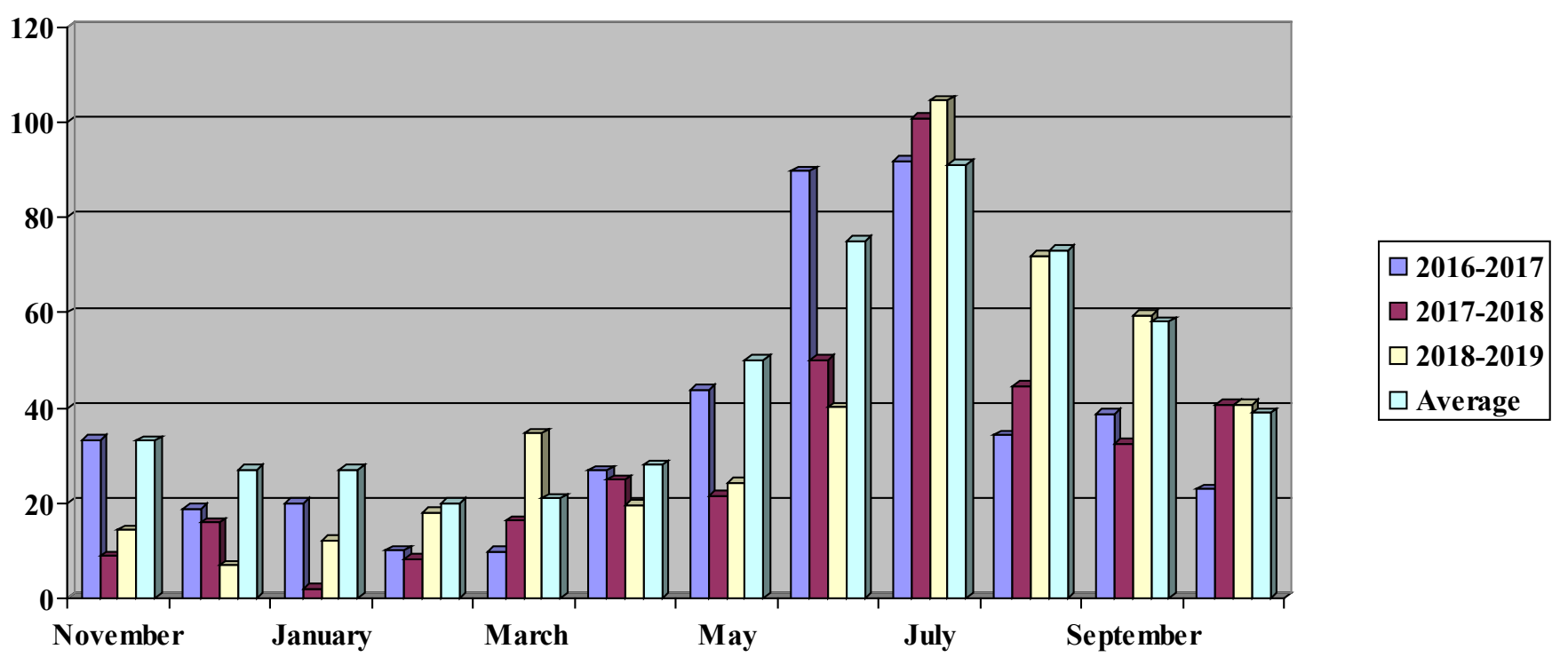

Fig. 2. The amount of precipitation during the research period in comparison with the average long-term data

The origin of the variety form in the experiment

\begin{tabular}{|c|c|c|}
\hline No. & Hybrid family & Variety form \\
\hline \multicolumn{3}{|c|}{ Introduced } \\
\hline 1 & $(27-3-63 \times$ Sunderbyun II $) \times$ Orlovskiy val's & Zaglyaden'e \\
\hline 2 & Ekzotika $\times 762-5-82$ & Kipiana \\
\hline 3 & (Bredtorp - open pollination) $\times$ Samoplodnaya & Chudnoe mgnovenie \\
\hline 4 & Plotnokistnaya $\times$ selected form & Gerkules \\
\hline 5 & Bredtorp $\times($ Zoya $\times$ Pushistaya $)$ & Zabava \\
\hline \multicolumn{3}{|c|}{ Breeding Sverdlovsk selection gardening station } \\
\hline 6 & No. 147-1/182 (Naslednitsa $\times$ Bredtorp $) \times$ Globus & $1-1-010-13$ \\
\hline 7 & Valovaya $\times$ Dobryy Dzhinn & $\begin{array}{l}1-2-010-13,1-3-010-13 \\
1-4-010-13\end{array}$ \\
\hline 8 & Dobryy Dzhinn $\times$ Globus + Dobryy Dzhinn & $\begin{array}{l}2-1-010-13,2-2-010-13 \\
2-3-010-13,2-4-010-13 \\
2-5-010-13\end{array}$ \\
\hline 9 & Globus $\times$ No. 147-1/182 (Naslednitsa $\times$ Bredtorp) & $3-1-010-13$ \\
\hline 10 & Valovaya $\times$ No.,147-1/182 (Naslednitsa $\times$ Bredtorp $)$ & $\begin{array}{l}3-2-010-13,3-3-010-13 \\
6-37-00-03,7-52-00-03 \\
7-63-00-03\end{array}$ \\
\hline 11 & Pilot $\times$ No. $147-1 / 182$ (Naslednitsa $\times$ Bredtorp) & $3-4-010-13$ \\
\hline 12 & Pilot $\times$ Dobryy Dzhinn & $4-1-010-13$ \\
\hline 13 & Krasa L'vova $\times$ Globus & $5-1-010-13,5-2-010-13$ \\
\hline 14 & No. $147-1 / 182($ Naslednitsa $\times$ Bredtorp $) \times$ Valovaya & $6-44-00-03$ \\
\hline 15 & Krasa L'vova $\times$ Dobryy Dzhinn & $8-1-010-13,8-2-010-13$ \\
\hline 16 & Valovaya-open pollination & $\begin{array}{l}\text { Ataman, Voevoda, Dobrokhot, Pilot, } \\
\text { Fortuna }\end{array}$ \\
\hline 17 & Khabarovskaya $\times$ Bredtorp & Vasilisa \\
\hline 18 & 31-4-a (39-19-61 × GAZ-1-45) × Akkord & Kornet \\
\hline 19 & Fertodi $\times$ Zelenaya dymka & Slavyanka \\
\hline 20 & Slavyanka $\times$ Valovaya & Udalets \\
\hline 21 & Globus $\times$ Valovaya & Shaman \\
\hline
\end{tabular}


Аграрный вестник Урала № 07 (198), 2020 г.

\begin{tabular}{|c|c|c|c|c|c|c|c|c|c|c|}
\hline & & \multirow{2}{*}{\multicolumn{3}{|c|}{$\frac{\text { Timi }}{2017}$}} & logical 1 & ases of blac & $k$ currant & varietie & the 201 & \\
\hline \multirow{3}{*}{ No. } & \multirow{3}{*}{ Variety form } & & & & \multicolumn{3}{|c|}{2018} & \multicolumn{3}{|c|}{2019} \\
\hline & & \multicolumn{3}{|c|}{ Start date } & \multicolumn{3}{|c|}{ Start date } & \multicolumn{3}{|c|}{ Start date } \\
\hline & & budding & flowering & \begin{tabular}{|l|} 
ripening \\
\end{tabular} & budding & flowering & ripening & budding & flowering & ripening \\
\hline 1 & 2 & 3 & 4 & 5 & 6 & 7 & 8 & 9 & 10 & 11 \\
\hline \multicolumn{11}{|c|}{ Introduced } \\
\hline 1 & Gerkules & 18.04 & 17.05 & 24.07 & 2.05 & 27.05 & 8.08 & 15.04 & 13.05 & 20.07 \\
\hline 2 & Zabava & 19.04 & 13.05 & 25.07 & 2.05 & 22.05 & 2.08 & 12.04 & 10.05 & 18.07 \\
\hline 3 & Zaglyaden'e & 18.04 & 17.05 & 29.07 & 2.05 & 24.05 & 10.08 & 17.04 & 12.05 & 23.07 \\
\hline 4 & Kipiana & 17.04 & 16.05 & 28.07 & 4.05 & 24.05 & 10.08 & 16.04 & 13.05 & 25.07 \\
\hline 5 & \begin{tabular}{|l} 
Chudnoe \\
mgnovenie
\end{tabular} & 18.04 & 14.05 & 28.07 & 1.05 & 24.05 & 10.08 & 12.04 & 11.05 & 25.07 \\
\hline \multicolumn{11}{|c|}{ Breeding Sverdlovsk selection gardening station } \\
\hline 6 & Ataman & 18.04 & 13.05 & 27.07 & 2.05 & 24.05 & 8.08 & 14.04 & 11.05 & 18.07 \\
\hline 7 & Vasilisa & 17.04 & 14.05 & 27.07 & 1.05 & 23.05 & 5.08 & 12.04 & 10.05 & 18.07 \\
\hline 8 & Voevoda & 18.04 & 13.05 & 25.07 & 2.05 & 24.05 & 4.08 & 14.04 & 10.05 & 18.07 \\
\hline 9 & Dobrokhot & 17.04 & 12.05 & 26.07 & 2.05 & 24.05 & 8.08 & 13.04 & 11.05 & 20.07 \\
\hline 10 & Kornet & 18.04 & 16.05 & 27.07 & 2.05 & 27.05 & 8.08 & 12.04 & 13.05 & 18.07 \\
\hline 11 & Pilot & 20.04 & 15.05 & 27.07 & 3.05 & 25.05 & 8.08 & 15.04 & 11.05 & 20.07 \\
\hline 12 & Slavyanka & 17.04 & 17.05 & 28.07 & 4.05 & 28.05 & 10.08 & 17.04 & 13.05 & 22.07 \\
\hline 13 & Udalets & 17.04 & 15.05 & 27.07 & 2.05 & 25.05 & 3.08 & 12.04 & 12.05 & 18.07 \\
\hline 14 & Fortuna & 17.04 & 12.05 & 27.07 & 3.05 & 23.05 & 8.08 & 15.04 & 10.05 & 20.07 \\
\hline 15 & Shaman & 19.04 & 15.05 & 26.07 & 3.05 & 24.05 & 2.08 & 17.04 & 13.05 & 20.07 \\
\hline 16 & $1-1-010-13$ & 19.04 & 16.05 & 26.07 & 3.05 & 25.05 & 2.08 & 15.04 & 12.05 & 17.07 \\
\hline 17 & $1-2-010-13$ & 18.04 & 13.05 & 28.07 & 3.05 & 24.05 & 2.08 & 17.04 & 10.05 & 19.07 \\
\hline 18 & $1-3-010-13$ & 17.04 & 13.05 & 26.07 & 1.05 & 22.05 & 8.08 & 12.04 & 10.05 & 18.07 \\
\hline 19 & $1-4-010-13$ & 19.04 & 13.05 & 27.07 & 3.05 & 24.05 & 2.08 & 16.04 & 10.05 & 20.07 \\
\hline 20 & $2-1-010-13$ & 17.04 & 15.05 & 24.07 & 2.05 & 24.05 & 2.08 & 16.04 & 11.05 & 17.07 \\
\hline 21 & 2-2-010-13 & 17.04 & 16.05 & 25.07 & 1.05 & 23.05 & 4.08 & 13.04 & 11.05 & 18.07 \\
\hline 22 & $2-3-010-13$ & 18.04 & 15.05 & 27.07 & 2.05 & 24.05 & 2.08 & 12.04 & 12.05 & 20.07 \\
\hline 23 & $2-4-010-13$ & 18.04 & 12.05 & 24.07 & 2.05 & 24.05 & 2.08 & 16.04 & 10.05 & 18.07 \\
\hline 24 & $2-5-010-13$ & 18.04 & 16.05 & 28.07 & 1.05 & 24.05 & 2.08 & 13.04 & 10.05 & 16.07 \\
\hline 25 & $3-1-010-13$ & 19.04 & 15.05 & 24.07 & 3.05 & 24.05 & 2.08 & 16.04 & 13.05 & 18.07 \\
\hline 26 & $3-2-010-13$ & 16.04 & 12.05 & 25.07 & 2.05 & 23.05 & 4.08 & 12.04 & 11.05 & 20.07 \\
\hline 27 & $3-3-010-13$ & 18.04 & 15.05 & 24.07 & 1.05 & 24.05 & 8.08 & 12.04 & 11.05 & 18.07 \\
\hline 28 & $3-4-010-13$ & 17.04 & 12.05 & 26.07 & 3.05 & 25.05 & 4.08 & 15.04 & 11.05 & 18.07 \\
\hline 29 & $4-1-010-13$ & 18.04 & 13.05 & 28.07 & 2.05 & 23.05 & 2.08 & 17.04 & 12.05 & 19.07 \\
\hline 30 & $5-1-010-13$ & 19.04 & 17.05 & 24.07 & 3.05 & 28.05 & 2.08 & 17.04 & 14.05 & 18.07 \\
\hline 31 & $5-2-010-13$ & 18.04 & 17.05 & 27.07 & 2.05 & 25.05 & 4.08 & 16.04 & 13.05 & 20.07 \\
\hline 32 & $6-37-00-03$ & 17.04 & 16.05 & 25.07 & 3.05 & 25.05 & 5.08 & 15.04 & 11.05 & 20.07 \\
\hline 33 & 6-44-00-03 & 17.04 & 12.05 & 26.07 & 1.05 & 23.05 & 3.08 & 13.04 & 11.05 & 16.07 \\
\hline 34 & $7-52-00-03$ & 17.04 & 12.05 & 25.07 & 3.05 & 23.05 & 2.08 & 16.04 & 12.05 & 20.07 \\
\hline 35 & 7-63-00-03 & 19.04 & 15.05 & 24.07 & 4.05 & 24.05 & 4.08 & 17.04 & 12.05 & 18.07 \\
\hline 36 & $8-1-010-13$ & 19.04 & 15.05 & 28.07 & 2.05 & 24.05 & 4.08 & 14.04 & 12.05 & 16.07 \\
\hline 37 & $8-2-010-13$ & 19.04 & 17.05 & 29.07 & 3.05 & 27.05 & 8.08 & 14.04 & 13.05 & 20.07 \\
\hline
\end{tabular}


Some of the cultivars classified as medium, in some years showed themselves as early, some of the accessions - as late, depending on weather conditions. So, varieties Dobrokhot, Ataman, Voevoda, Vasilisa, 1-2-010-13, 1-4-010-13, 2-2-010$13,2-4-010-13,4-1-010-13,7-52-00-03$ during the years of research were twice marked as early flowering; cultivars Kipiana, Kornet, 5-2-010-13 - as late flowering. Variety samples Voivoda, Udalets, 1-1-010-13, 2-2-010-13, 2-5-010-13, 3-3$010-13,6-44-00-03,7-52-00-03,7-63-00-03$ over the years of the study were twice marked as early maturing. Samples 1-2-010-13, 2-5-010-13, 4-1-010-13, 8-1-010-13, 8-2-010-13 in 2017 were marked as late maturing.

\section{Discussion and Conclusion}

1. Black currant adapts well to the unstable weather conditions of recent years in the Middle Urals.

2. The shift in the dates of the onset of the main phases of the growing season can reach 14 days, nevertheless, all phases fit into the growing season due to a reduction or increase in the duration of one or another phase.
3. The introduced varieties pass through phenological phases at the same time as those bred in the Middle Urals.

4. As a result of the research carried out, five early flowering varieties were identified in the conditions of the Middle Urals: Zabava, Fortuna, 1-3-010-13, 3-2-010-13, 6-44-00-03; four late flowering: Hercules, Slavyanka, 5-1-010-13, 8-2010-13; the remaining 28 cultivars have an average flowering period. Five varieties of early ripening were identified: Zabava, 2-1-010-13, 2-4-010-13, 3-1-010-13, 5-1-010-15; four late ripening periods: Zaglyadenie, Kipiana, Chudnoe mgnovenie, Slavyanka; the remaining 28 varieties have an average ripening period.

\section{Acknowledgements}

The studies were carried out within the framework of the 148th Program of the Basic Research Institute of State Academies of Sciences for 2013-2020. on the topic "Preservation, replenishment, study of genetic collections and allocation of new donors and genetic sources of economically useful traits of fruit and berries, cereals, legumes, forage crops and potatoes" No. 0773-2019-0023.

\section{References}

1. Shagina T. V. Itogi selektsii chernoy smorodiny [Black currant breeding results] // Perspektivy severnogo sadovodstva na sovremennom etape: materialy nauchno-prakticheskoy konferentsii, posvyashchennoy 70-letiyu so dnya obrazovaniya GU SSSS, Ekaterinburg, 2005. Pp. 166-171. (In Russian.)

2. Nikolaev A. V., Knyazev S. D. Fenologicheskiye ritmy otbornykh form chernoy smorodiny [Phenological rhythms of selected forms of blackcurrant] // Selektsiya i sortorazvedenie sadovykh kul'tur. Orel, 2007. Pp. 147-152. (In Russian.)

3. Gabysheva N. S., Protopopova A. V., Sorokopudov V. N. Ekologicheskie aspekty fenoritmiki sortov smorodiny chernoy $\mathrm{v}$ usloviyakh Tsentral'noy Yakutii [Ecological aspects of the phenorhythmics of blackcurrant varieties in the conditions of Central Yakutia] // Contemporary horticulture. 2017. No. 3. Pp. 26-34. DOI: 10.24411/2218-5275-2017-00012. (In Russian.)

4. Akulenko E. G. Fenologicheskie ritmy sezonnogo razvitiya smorodiny chernoy v usloviyakh Bryanskoy oblasti [Phenological rhythms of the seasonal development of black currant in the conditions of the Bryansk region] // Vestnik Bryanskoy gosudarstvennoy sel'skokhozyaystvennoy akademii. 2016. No. 1 (53). Pp. 13-17. (In Russian.)

5. Sorokopudov V. N., Burmenko Yu. V. Smorodina zolotistaya (Ribes aureum Pursh.): biologicheskiye osobennosti i perspektivy kul'tivirovaniya [Golden Currant (Ribes aureum Pursh.): Biological Features and Cultivation Prospects]: Monograph. Moscow: FGBNU VSTISP. 2017. 130 p. (In Russian.)

6. Kozlova A. B., Zakharova E. B., Chernositova T. N. Otsenka razvitiya i produktivnosti perspektivnykh sortov shipovnika v usloviyakh Blagoveshchenska [Assessment of the development and productivity of promising rosehip varieties in Blagoveshchensk] // Agricultural Journal in the Far East Federal District. 2018. No. 4 (48). Pp. 93-97. DOI: 10.24411/19996837-2018-14086. (In Russian.)

7. Rengarten G. A., Sorokopudov V. N. Otsenka sortoobraztsov cheremukhi v zavisimosti ot ikh geneticheskogo proiskhozhdeniya na Severo-Vostoke Rossii [Assessment of bird cherry variety varieties depending on their genetic origin in the NorthEast of Russia] // Vestnik KrasGAU. 2019. No. 3. Pp. 51-56. (In Russian.)

8. Imrak B., Kuden A., Yutkula V. [et al.] Evaluation of Some Phenological and Biochemical Characteristics of Selected New Late Flowering Dried Apricot Cultivars // Biochemical Genetics. 2017. No. 55 (3). Pp. 234-243. DOI: 10.1007/s10528-0179792-y.

9. Batmanova E. M. Sozdaniye i otsenka genofonda smorodiny chernoy v usloviyakh Srednego Urala: dis. ... cand. s.-kh. nauk [Creation and evaluation of the blackcurrant gene pool in the conditions of the Middle Urals: dissertation ... candidate of agricultural sciences]. Barnaul, 2011. 185 p. (In Russian.)

10. Katalog sortov: proiskhozhdeniye i opisaniye sortov smorodiny chernoy [Variety catalog: origin and description of varieties of black currant] [e-resource] // Ofitsial'nyy sayt FGBNU VNIISPK. URL: https://vniispk.ru/varieties (appeal date: 20.04.2020). (In Russian.)

11. Morozova O. I., Dudkin D. V., Kuznetsova S. B. Fenologicheskaya otsenka prigodnosti agroklimaticheskikh resursov Khanty-Mansiyskogo avtonomnogo okruga dlya vozdelyvaniya chernoy smorodiny (Ribes nigrum) [Phenological assessment of the suitability of agroclimatic resources of the Khanty-Mansiysk Autonomous District for cultivation of black currant (Ribes nigrum)] // Kontseptsii fundamental'nykh i prikladnykh nauchnykh issledovaniy: sbornik statey mezhdunarodnoy nauchnoprakticheskoy konferentsii: v 4 chastyakh. 2017. Pp. 233. (In Russian.)

12. Rodyukova O. S. Adaptivnyy i produktivnyy potentsialy geneticheskoy kollektsii smorodiny chernoy [Adaptive and productive potentials of the genetic collection of blackcurrant] // Sovremennyye tendentsii ustoychivogo razvitiya yagodo- 
vodstva Rossii (smorodina, kryzhovnik): sbornik nauchnykh trudov, posvyashchennyy 110-letiyu so dnya rozhdeniya doktora sel'skokhozyastvennykh nauk, zasluzhennogo deyatelya nauki RSFSR K. D. Sergeyevoy. Voronezh, 2018. Pp. 225-243. (In Russian.)

13. Chaplygina T. A. Sortoizucheniye chernoy smorodiny selektsii VNIISPK v usloviyakh Samarskoy oblasti [Varietal study of black currant VNIISPK breeding in the Samara region] // Selektsiya i sortorazvedeniye sadovykh kul'tur: materialy Mezhdunarodnoy nauchno-prakticheskoy konferentsii, posvyashchennoy 170-letiyu VNIISPK. 2015. Pp. 227-230. (In Russian.)

14. Sabaraykina S. M. Biologicheskiye osobennostirostairazvitiya sortov smorodiny chernoy vusloviyakh rezkokontinental'nogo klimata [Biological features of the growth and development of varieties of black currant in a sharply continental climate] // Nauchnaya zhizn'. 2016. No. 8. Pp. 65-78. (In Russian.)

15. Sorokopudov V. N., Baranova T. V., Voronin A. A. Osobennosti ekologii i fenologii Ribes Aureum v usloviyakh sovremennykh klimaticheskikh izmeneniy [Features of the ecology and phenology of Ribes Aureum in the context of modern climate change] // Global'nyye klimaticheskie izmeneniya: regional'nyye effekty, modeli, prognozy: materialy mezhdunarodnoy nauchno-prakticheskoy konferentsii. Voronezh, 2019. Pp. 178-181. (In Russian.)

16. Anatov D. M., Osmanov R. O. Fenologicheskiye osobennosti nachal'nykh faz tsveteniya i vegetatsii kul'tivarov abrikosa Dagestana [Phenological features of the initial phases of flowering and vegetation of apricot cultivars of Dagestan] // Agrarian Bulletin of the Urals. 2019. No. 12 (191). Pp. 31-39. DOI: 10.32417/1997-4868-2019-191-12-31-39. (In Russian.)

17. Aleynikova G. Yu., Petrov V. S., Sokolova V. V. Tendentsii lokal'nogo izmeneniya klimata i ikh vliyaniye na produktivnost' $\mathrm{i}$ fenologiyu vinograda [Trends in local climate change and their impact on the productivity and phenology of grapes] // Nauchnyye trudy Severo-Kavkazskogo federal'nogo nauchnogo tsentra sadovodstva, vinogradarstva, vinodeliya. 2019. T. 23. Pp. 117-125. DOI: 10.30679/2587-9847-2019-23-117-125. (In Russian.)

18. Avdeyeva Z.A., Aminova Ye.V. Vliyaniye pogodnykh usloviy perioda vegetatsii na prokhozhdeniye fenologicheskikh faz u sortov zemlyaniki [The influence of weather conditions of the growing season on the passage of phenological phases in strawberry varieties] // Byulleten' Orenburgskogo nauchnogo tsentra UrO RAN. 2019. No. 4. P. 19. DOI: 10.24411/2304-90812019-14032. (In Russian.)

19. Programma i metodika sortoizucheniya plodovykh, yagodnykh i orekhoplodnykh kul'tur [The program and methodology of variety studies of fruit, berry and nut-bearing crops] / Under the editorship of E. N. Sedov. Orel: VNIISPK, 1999.608 p. (In Russian.)

20. Programma i metodika sortoizucheniya plodovykh, yagodnykh i orekhoplodnykh kul'tur [The program and methodology of variety studies of fruit, berry and nut-bearing crops]. Michurinsk, 1973. 495 p. (In Russian.)

\section{Authors'information:}

Elena M. Chebotok ${ }^{1}$, candidate of agricultural sciences, senior researcher, ORCID 0000-0001-5942-6178, AuthorID 501549; +7 (343) 258-65-01, sadovodnauka@mail.ru

${ }^{1}$ Ural Federal Agrarian Research Center of the Ural Branch of the Russian Academy of Sciences, Ekaterinburg, Russia 